\title{
ANALISIS KESALAHAN BERBAHASA INDONESIA BIDANG EJAAN PADA SURAT KABAR TRIBUN NEWS
}

\author{
Fahriza Ramadhan ${ }^{1}$ \\ Universitas Ahamad Dahlan \\ fahriza1800003143@webmail.uad.ac.id \\ Atika Dwi Maretnowati ${ }^{2}$ \\ Universitas Ahmad Dahlan \\ atika1800003142@webmail.uad.ac.id \\ Nursulaiman $^{3}$ \\ Universitas Ahmad Dahlan \\ nursualiman1800003147@webmail.uad.ac.id \\ Muhammad Rizal Syahputra ${ }^{4}$ \\ Universitas Ahmad Dahlan \\ muhammad1800003144@webmail.uad.ac.id
}

\begin{abstract}
ABSTRAK
Bahasa terorganisasi dalam satuan-satuan, seperti kata, klausa dan kalimat yang di ungkapkan secara lisan ataupun secara tulis. Tujuan penelitian ini adalah mengetahui apa ajakan kesalahan berbabahasa Indonesia bidang ejaan dari surat kabar Tribun News, Teknik pengumpulan data yang digunakan dalam penelitian ini adalah teknik simak dan catat. Hal tersebut karena objek dalam penelitian ini merupakan kata dan kalimat yang terdapat pada surat kabar harian Tribun News edisi 26 Mei 2021. Teknik analisis data peneliti melakukan reduksi data yaitu memilih data yang sesuai dengan ejaan. Peneliti selanjutnya, melakukan penyajian data dengan cara deskripsi data. Langkat terakhir peneliti melakukan penarikan simpulan berkaiatan dengan analisis kesalahan berbahasa pada ejaan. Hasil Penelitian dari penelitian ini yang terdapat pada surat kabar Tribun News edisi 26 Mei 2021, kesalahan yang ditemukan terbagi menjadi 12 data kesalahan pada huruf dan 1 data untuk kesalahan tanda baca.
\end{abstract}

Kata Kunci: Bahasa, Bidang Ejaan, Tribun News

\section{A. PENDAHULUAN}

Bahasa merupakan alat komunikasi, bahasa biasa digunakan di dalam masyarakat. Bahasa juga terorganisasi dalam satuan-satuan, seperti kata, klausa dan kalimat yang di ungkapkan secara lisan ataupun secara tulis. Menurut Gorys Keraf (2004), bahasa adalah alat komunikasi antara masyarakat berupa simbol bunyi yang dihasilkan oleh alat ucap manusia. Akan tetapi, penggunaan bahasa sering mengalami kesalahan sehingga muncul banyak penelitian mengenai kesalahan berbahasa. Analisis kesalahan berbahasa merupakan usaha mengatasi bentuk penyimpangan bahasa dan mempunyai dampat positif terhadap efektivitas bahasanya serta dapat diterima sebagai kasanah sistem bahasa yang bersangkutan. Menurut 
Hudhana, Wiharja, dan Fitriani, (2021) kesalahan berbahasa dapat diartikan sebagai kesalahan dalam penggunaan bahasa yang tidak sesuai dengan kaidah kebahasaan. Kesalahan bahasa adalah penyimpangan dari sebuah yang biasa berlaku dalam bahasa itu menurut kriteria yang dianut oleh penutur aslinya.

Surat kabar merupakan salah satu media yang membantu pembelajaran bahasa Indonesia kepada masyarakat. Surat kabar yang menggunakan bahasa yang baik dan benar secara tidak langsung telah bertindak langsung sebagai pembina bahasa bagi generasi yang lebih muda dan pembaca-pembacanya (Nisa, 2018). Surat kabar secara tidak langsung telah sepeti Pembina bahasa Indonesia karena dalam surat kabar menggunakan bahaa yang baik dan berdampak positif bagi Surat kabar yang menggunakan bahasa yang baik dan benar secara tidak langsung telah bertindak langsung sebagai pembina bahasa bagi generasi yang lebih muda dan pembaca-pembacanya.

Kesalahan berbahasa juga terjadi dalam surat kabar. Ketika orang membaca surat kabar, kadang kala tidak meneliti kebahasanya, padahal belum tentu setiap wacana tidak terdapat kesalahan. Kesalahan-kesalahan itu muncul karena dalam pembuatannya tidak berpedoman pada kaidah-kaidah bahasa yang benar (Nisa, 2018). Oleh karena itu, penelitian ini mengambil penelitian tentang kesalahan berbahasa dalam surat kabar Tribun News. Peneliti mengambil data secara online dari web surat kabar Tribun News. Surat kabar tersebut selalu update selang hari setelah terbitnya surat kabar baru. Tribun News adalah kelompok surat kabar daerah yang dimiliki oleh Kompas Gramedia. Saat ini, kelompok ini telah menerbitkan 29 surat kabar daerah, yang tersebar di 24 kota dan kabupaten di Indonesia. Tujuan penelitian ini yaitu mengetahui kesalahan ejaan dalam Koran Tribun News.

Penelitian dilakukan oleh Hermawan, Ferawati dan Citra (2020) dengan judul Analisis Kesalahan Berbahasa Bidang Sintaksis Rubrik Keluarga Surat Kabar Kedaulatan Rakyat Edisi 16 Februari 2020 berisi tentang penulisan berita dalam surat kabar Kedaulatan Rakyat ini masih sering dijumpai kesalahan berbahasa pada bidang sintaksis. Di dalam penelitian ini banyak ditemukan kesalahan pada penggunaan kata mubazir, pemilihan kata yang kurang tepat, dan anafora (rujukan silang yang kurang tepat). Kesalahan tersebut diakibatkan kurangnya memperhatikan kaidah kebahasaan yang baik dan benar seperti yang ada dalam KBBI dan PUEBI.

\section{B. METODOLOGI PENELITIAN}

Penelitian ini merupakan jenis penelitian kualitatif deskriptif yaitu berupa kata-kata maupun kalimat. Dalam penelitian kualitatif kegiatan penyediaan data merupakan kegiatan 


\section{Lingua Rima: Jurnal Pendidikan Bahasa dan Sastra Indonesia \\ Vol. 10 No. 3 September 2021 \\ http://jurnal.umt.ac.id/index.php/lgrm}

yang berlangsung secara simultan dengan kegiatan analisis data. Analisis kualitatif fokusnya pada penunjukan makna, deskripsi, penjernihan, dan penempatan data pada konteksnya masing-masing dan sering kali melukiskannya dalam bentuk kata-kata daripada angka-angka (Mahsun, 2005). Objek penelitian dalam penelitian ini adalah surat kabar harian Tribun News edisi 26 Mei 2021. Data dalam penelitian ini menggunakan data kualitatif, yaitu data yang terkumpul berupa kata dan kalimat yang merupakan kesalahan berbahasa bidang ejaan, morfologi, semantik dan sintaksis pada surat kabar harian Tribun News edisi 26 Mei 2021. Teknik pengumpulan data yang digunakan dalam penelitian ini adalah teknik simak dan catat. Hal tersebut karena objek dalam penelitian ini merupakan kata dan kalimat yang terdapat pada surat kabar harian Tribun News edisi 26 Mei 2021. Teknik analisis data dalam penelitian ini, peneliti melakukan reduksi data yaitu memilih data yang sesuai dengan ejaan. Peneliti selanjutnya, melakukan penyajian data dengan cara deskripsi data. Langkat terakhir peneliti melakukan penarikan simpulan berkaiatan dengan analisis kesalahan berbahasa pada ejaan.

\section{HASIL PENELITIAN DAN PEMBAHASAN}

Hasil Penelitian dari penelitian ini yang terdapat pada surat kabar Tribun News edisi 26 Mei 2021, Kesalahan yang ditemukan terbagi menjadi 2 jenis kesalahan yaitu kesalahan penggunaan huruf dan penggunaan tanda baca.

\section{Penggunaan Huruf}

Data 1

Pada halaman 1 sub judul (Menikmati Bulan Super Merah) terdapat kesalahan penulisan yang seharusnya dimiringkan karena termasuk bahasa asing yaitu pada kata Super Blood Moon yang seharusnya Super Blood Mood. Selanjutnya pada sub judul (Dua Orang Meninggal Dunia) juga terdapat kesalahan penulisan yang seharusnya dimiringkan karena termasuk bahasa asing yaitu Covid-19 yang seharusnya Covid-19. Pada sub judul (Hanya Ada Satu Pintu) juga terdapat kesalahan penulisan yaitu kata Covid-19 yang seharusnya Covid-19 dan kata lockdown mikro yang seharusnya Lockdown Mikro). Kemudian pada sub judul (Semprot Pestisida di Lahan 10 Hektare per Hari) terdapat kesalahan tanda baca pada kalimat kedua "Frogs Indonesia, perusahaan milik anak bangsa, pun mencoba membantu....." yang seharusnya "Frogs Indonesia, perusahaan milik anak bangsa pun, mencoba membatu.....”. Selanjutnya pada kata drone sprayer yang seharusnya dicetak miring karena termasuk bahasa asing drone sprayer. 


\section{Lingua Rima: Jurnal Pendidikan Bahasa dan Sastra Indonesia \\ Vol. 10 No. 3 September 2021 \\ http://jurnal.umt.ac.id/index.php/lgrm}

\section{Data 2}

Pada halaman 2 sub judul (Pak RT Agen Pengendalian Covid-19) terdapat kesalahan penulisan sub judul yang seharusnya (Pak RT Agen Pengendalian Covid-19). Selanjutnya terdapat kesalahan penulisan pada kata Kalurahan yang seharusnya Kelurahan, karena di KBBI tidak ada istilah kata Kalurahan yang ada Kelurahan yang artinya daerah pemerintahan yang paling bawah yang dipimpin oleh seorang lurah. Pada paragraf ke empat juga terdapat kesalahan penulisan yaitu pada kata tracing yang seharusnya tracing karena termasuk bahasa asing. Berikutnya pada kata diiisolasi penulisannya seharusnya diisolasi. Kemudian pada paragraf ke lima terdapat kalimat yang tidak efektif yaitu 'Yang paling penting tentu adalah para RT dan RW ini sudah paham dan sadar betul bawah covid-19 nyata dan tak boleh dianggap sepele' yang seharusnya 'Hal yang terpenting adalah para RT dan RW sudah paham dan sadar bahwa Covid-19 memang nyata dan tidak boleh dianggap sepele'. Selanjutnya pada paragraf ke enam terdapat kesalahan penulisan pada kata memiling peran yang seharusnya memiliki peran. Kemudian pada paragraf ke sembilan terdapat kesalahan pemilihan kata, pada emoh seharusnya diganti tidak ingin karena kata emoh bukan merupakan kosa kata bahasa Indonesia namun bahasa Jawa.

Data 3

Pada halaman 4 bagian sub judul (Penularan Meluas, 106 Tiga Kalurahan Jalani Uji Asap) dalam berita tersebut terdapat kalimat " Lurah Sumbermulyo, Ani Widayani mengungkapkan warga kembangan kutu yang terkonfimasi positif Covid-19 telah menjalani isolasi." pada kata "Terkonfimasi", terdapat kekurangan huruf yang seharusnya kata tersebut yang benar "Terkonfirmasi"

Data 4

Pada halaman 4 bagian sub judul Laut Bergejolak terdapat kalimat "Fenomena Super Blood Moon memicu terjadinya gelombang tinggi di perairan selatan Di Yogyakarta"pada kata "Super Blood Moon” seharunya di miringkan menjadi "Super Blood Moon”

Data 5

Pada Halaman 5 bagian subjudul Pemda DIY Buka 56 Formasi CPNS terdapat Kalimat "Hingga saat ini masih banyak jabatan eselon dua yang disi oleh pelaksana tugaas (plt) sehingga membuat kinerja OPD menjadi tak optimal." Terdapat kelebihan huruf pada kata "tugaas"seharusnya di hilangkan satu huruf menjadi "Tugas" 
Data 6

Pada Halaman 5 bagian subjudul Kasus Covid-19 Bertambahan 190 Pasien terdapat Kalimat "Adapun rincian riwayat sementara kasus terkonfirmasi Covid-19 adalah periksa mandiri 25 kasus, perjalanan luar daerah satu kasus, dan tracing kontak kasus positif 144 kasus. Terdapat kata yang seharusnya dimiringkan yaitu kata "trancing" seharusnya di miringkan menjadi "trancing"

Data 7

Berita yang diberikan oleh jogja.tribunnews, tanggal 16 Mei 2021, halaman 7 yang berjudul "Berhaya Orangtua Bertengkar di Hadapan Buah Hati". Pada berita tersebut terdapat kalimat "Jika pertengkaran berubah menjadi perkelahian besar, hal itu dapat berdampak bagi si kecil. Dilansir dari laman Parenting Firstcry". Pada kata "Pareting Firstery" seharusnya ditulis miring menjadi "Jika pertengkaran berubah menjadi perkelahian besar, hal itu dapat berdampak bagi si kecil. Dilansir dari lama Parenting Firstcry".

Data 8

Berita yang diberikan oleh jogja.tribunnews, tanggal 16 Mei 2021, halaman 7 yang berjudul "Tips Simpan ASI Agar Tidak Cepat Basi”. Pada berita tersebut terdapat kalimat “...tertutup atau wadah plastic keras yang tidak dibuat dengan bahan kimia bisphenol A (BIPA). Pata kata "bisphenol A" seharusnya ditulis miring menjadi “...tertutup atau wadah plastic keras yang tidak dibuat dengan bahan kimia bishenol $A$ (BIPA)".

Data 9

Berita yang diberikan oleh jogja.tribunnews, tanggal 16 Mei 2021, halaman 9 yang berjudul "Diplot Jadi Gelandang”. Pada berita tersebut terdapat kalimat "Musim 2019 lalu, dia masuk dalam UEFA Team of the Year bersama Lionel Messi, dan Cristiano Ronaldo". Pada kata "UEFA Team of the Year" seharusnya ditulis miring menjadi "Musim 2019 lalu, dia masuk dalam UEFA Team of the Year bersama Lionel Messi, dan Cristiano Ronaldo". Karena bahasa Inggris, yang artinya "Tim Penggemar UEFA tahun ini”.

Data 10 


\section{Lingua Rima: Jurnal Pendidikan Bahasa dan Sastra Indonesia \\ Vol. 10 No. 3 September 2021 \\ http://jurnal.umt.ac.id/index.php/lgrm}

Selanjutnya, pada kalimat “...juga para fans yang mengkritik keputusannya”. Pada kata "Fans" seharusnya ditulis miring menjadi “...juga para fans yang mengkritik keputusannya". Karena kata "fans" berasal dari bahasa Inggris yang artinya penggemar.

Data 11

Data selanjutnya, "Dia seorang playmaker dari bek kanan". Pada kata "playmaker" seharusnya ditulis miring menjadi "Dia seorang playmaker dari bek kanan". Karena bersal dari bahasa Inggris yang artinya dalam sepak bola asosiasi, playmaker adalah pemain yang ofensif tim, dan sering terlibat dalam gerakan passing yang mengarah ke tujuan, melalui visi, teknik, control bola, kreativitas, dan kemampuan passing mereka.

\section{Data 12}

Pada data selanjutnya, "Loew dipaksa mengandalkan penyerang bertipe false nine seperti Werner, Kai Havertz, Mueller, dan Volland". Pada kata "false nine" seharusnya ditulis miring menjadi "Loew dipaksa mengandalkan penyerang bertipe false nine seperti Werner, Kai Havertz, Mueller, dan Volland”. Karena kata tersebut berasal dari bahasa Inggris yang berarti sembilan palsu. False nine adalah peran dalam sebuah taktik untuk tim yang tidak memiliki pemain bertipe penyerang konvensional. Penyerang konvensional adalah pemain yang bisa menerima umpan silang, memantulkan bola, dan menyergap bola terobosan untuk dikoversikan menjadi gol, atau biasa dikenal pormasi pembohong belaka.

2. Kesalahan Tanda Baca

\section{Data 1}

Kesulitannya adalah, dia tak punya kesempatan menjadi gelandang di Liverpool". Pada kalimat tersebut seharusnya sehabis kata adalah tidak ada penggunaan tanda (,). Jadi penulisannya menjadi "Kesulitannya adalah dia tak punya kesempatan menjadi gelandangan di Liverpool".

\section{SIMPULAN DAN SARAN}

Berdasarkan Pembahasan di atas dapat di sumpulkan masih terdapat kesalahan berbahasa pada bidang ejaan di laman Surat Kabar online di Tribun News edisi 26 Mei 2021 adalah sebagai berikut 12 data kesalahan pada huruf dan 1 data untuk kesalahan Tanda Baca. Saran untuk peneliti selanjutnya yaitu peneliti berharap bahwa penelitian ini dapat menjadi acuan penelitian selanjutnya berkaitan dengan kesalahan berbahasa dalam hal ejaan pada surat kabar, agar surat kabar dapat memperbaiki dalam penggunaan bahasa pada artikel yang disajikan. 
Lingua Rima: Jurnal Pendidikan Bahasa dan Sastra Indonesia

Vol. 10 No. 3 September 2021

http://jurnal.umt.ac.id/index.php/lgrm

\section{E. DAFTAR PUSTAKA}

Hermawan, M. A., Ferawati, L., dan Citra, R. 2020. Analisis Kesalahan Berbahasa Bidang Sintaksis Pada Rubrik "Keluarga" Surat Kabar Kedaulatan Rakyat Edisi 16

Februari 2020. Journal of Humanities. Vol 2 No 2 Hal 115-122

Hudhana, W.D., Wiharja, I.A., dan Fitriani, H.S.H. 2021. Bentuk Kesalahan Kalimat dalam Karya Ilmiah Mahasiswa BIPA Thailand. Lingua Rima. Vol 10 No 2 Hal 43-50

Keraf, Gorys. (1985). Komposisi. Ende, Flores: Nusa Indah.

Mahsun. (2005). Metode Penelitian Bahasa: Tahapan Strategi, Metode,dan Tekniknya. Jakarta: Rajawali Pers.

Nisa, K. 2018. Analisis Kesalahan Berbahasa Pada Berita dalam Media Surat Kabar Sinar Indonesia Baru. Jurnal BIndo Sastra. Vol 2 No 2 Hal 218-224

. 2019. Analisis Kesalahan Berbahasa Tiga Berita Pilihan Pada Surat Kabar Sinar Indonesia Baru Edisi November 2017. Jurnal Komunitas Bahasa. Vol 6 No 1 Hal 5461 